\title{
Syntheses of Condensation Polymers and Addition Polymers
}

\section{Syntheses of High Polymers Containing Two Different Linkages by Polyaddition or Polyaddition-condensation}

By Ryohei Oda, Shohei Tokiura, Akira Miyasu and Masaya Okano

Some unsymmetrical compounds were synthesized, which contain acryloyl or epoxy group as one terminal group, and one of acryloyl, epoxy, ester and urethane groups as the other (e.g., $\mathrm{CH}_{2}-\mathrm{COX}-\mathrm{R}-\mathrm{COOCH}_{2}-\mathrm{CH}^{\prime} \mathrm{O}_{2}, \quad \mathrm{CH}_{2}=\mathrm{CHCOX}-\mathrm{R}-\mathrm{COOC}_{2} \mathrm{H}_{5}, \mathrm{CH}_{2}-\mathrm{CH}^{\prime}-\mathrm{CH}_{2} \mathrm{OCO}-\mathrm{R}-$

$\mathrm{NHCOOC}_{2} \mathrm{H}_{5}$, where $\mathrm{X}=\mathrm{O}$, NH; $\left.\mathrm{R}=\left(\mathrm{CH}_{2}\right)_{5}, \mathrm{p}-\mathrm{C}_{6} \mathrm{H}_{4}\right)$. Syntheses of polymers containing two different linkages were attempted by the polyaddition or polyaddition-condensation reactions of above compounds with aliphatic diamine, diol or amino-alcohol of 4 or 6 carbon atoms. The polyaddition-condensations between hexamethylenediamine and each of ethyl $\mathrm{N}$-acryloylp-aminobenzoate, $\mathrm{N}$-carbethoxy-p-aminobenzoic acid glycidyl ester or $\mathrm{N}$-carbethoxy- $\varepsilon$-aminocaproic acid glycidyl ester produced light yellow hard resins with a softening point of ca. $140^{\circ} \mathrm{C}$.

第 3 報 重縮合により 2 種の絬合が 2 つずつ交互に並んだ

高分子の合成（その 1 )

(1958 年 9 月 29 日受理)

小田良平・時浦昌平・美安 明・阔野正弥

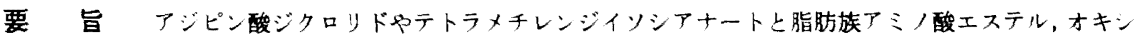
酸エステル、ジアミンのモノウレタン化物,アミノアルコールのウレタン化物との反応で,ポリメチレン鎖をは さんで 2 個の酸アミド，エステル，尿素、ウレタン結合を分子の中央に有する種々のジェステルやジウレタンを 合成した。つきにこれら長鎖ジエステルまたはジウレタンと脂肪族ジアミン,ジオールとの重縮合で, 2 種の結 合が2つずつ交互に規則正しく並んだ高分子をつくった。そのうちポリアミド・尿素ではかなりの曳系性を認 めたが，2 種の結合の1つにエステルを含むものでは曳糸性のないことを知った。
}

䇠者らは第 1 報1)において非対称 2 官能性化合物どう ，ままは対称，非対称 2 官能性化合物間の重縮合によ 2 種の結合を持つ高分子の台成について述べたが，こ 方法では反応に関与する 4 つの官能基の反応性の洁が 铛でないと，生成高分子中に 2 種の結台が規則正しく 列することが困難な場合が多い。一方合成繊維として ，可能性からすると当然結合の規則正しい配列が望まし 、今その 1 つとして 2 種の結合が 2 つずつ交互に規則 汭く並んだ場合を, 酸アミド, エステル，尿尔，ウレ ンの 4 結合の組合せについて考えると，次の 6 とおり :可能である。

[I] -(酸了ミド)-(酸丁ミド)-(エステル)-(エステル)[II] -(酸アミド)-(酸アミド)-(尿素)-(尿素)[III] -(酸アミド)-(酸アミド)-(ウレタン)-(ウレタン)-
[IV] -(エステル)-(エステル)-(尿素)-(体素)-

[V] -(エステル)-(エステル)-(ウレタン)-(ウレタン)-

[VI] -(瓜素)-(杘素)-(ウレタン)-(ウレタン)-

このらち各結合がポリメチレン鎖でつながり, [II],

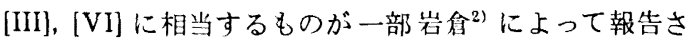
れているが，系統的な研究はない。すなわち氏はまずポ リメチレンジイソシァナートと $\omega$ アアミノ酸、または $\omega$ オキシ酸の反応で分子の中央に 2 個の尿素, またはウレ タン結合をもつジカルボン酸(またはエステル) HOOC$\left(\mathrm{CH}_{2}\right)_{m} \mathrm{HNOCHN}\left(\mathrm{CH}_{2}\right)_{n} \mathrm{NHCONH}\left(\mathrm{CH}_{2}\right)_{m} \mathrm{COOH},(n=4$, $6,8 ; \quad m=1,4,5), \quad \mathrm{H}_{5} \mathrm{C}_{2} \mathrm{OOC}\left(\mathrm{CH}_{2}\right)_{m} \mathrm{OOCHN}\left(\mathrm{CH}_{2}\right)_{n} \mathrm{NH}-$ $\mathrm{COO}\left(\mathrm{CH}_{2}\right)_{m} \mathrm{COOC}_{2} \mathrm{H}_{5},(n=4 ; m=4,5)$ をつくり, これ とへキサメチレンジアミンの重縮合で [II], [III] に相当 する高分子を，また同様に尿素結合 2 個を含むジオール 
$\mathrm{HO}\left(\mathrm{CH}_{2}\right)_{5} \mathrm{HNOCHN}\left(\mathrm{CH}_{2}\right)_{6} \mathrm{NHCONH}\left(\mathrm{CH}_{2}\right)_{5} \mathrm{OH}$ をテトラ メチレンジィソシァナートと反応させて，[VI] に相当す るものを得ている。

われわれはまずアジピン酸からアジピン酸ジクロリ ド, テトラメチレンジイソシァナートをつくり，これを 原料とし，次の過程に従い中央に酸アミド，またはエス テル結合を 2 個有するジェステル (ジカルボン酸) (A-1, $\left.\mathrm{A}^{\prime}-1, \mathrm{~A}-2\right)$ またはジゥレタン $(\mathrm{A}-3, \mathrm{~A}-4)$ を，同様に尿 素, またはウレタン結合を 2 個有するジウレタン (B-1, B-2)またはジェステル (B-3)を合成した。

$$
\mathrm{ClOC}\left(\mathrm{CH}_{2}\right)_{4} \mathrm{COCl}+\left\{\begin{array}{l}
\mathrm{NH}_{2}\left(\mathrm{CH}_{2}\right)_{5} \mathrm{COOC}_{2} \mathrm{H}_{5} \\
\mathrm{HO}\left(\mathrm{CH}_{2}\right)_{5} \mathrm{COOC}_{2} \mathrm{H}_{5} \\
\mathrm{NH}_{2}\left(\mathrm{CH}_{2}\right)_{6} \mathrm{NHCOOC}_{2} \mathrm{H}_{5} \\
\mathrm{HO}\left(\mathrm{CH}_{2}\right)_{6} \mathrm{NHCOOC}_{2} \mathrm{H}_{5}
\end{array}\right\} \underset{\mathrm{K}_{2} \mathrm{CO}_{3}}{\stackrel{\text { ベンビン中 }}{\longrightarrow}}
$$

$\mathrm{H}_{5} \mathrm{C}_{2} \mathrm{OOC}\left(\mathrm{CH}_{2}\right)_{5} \mathrm{HNOC}\left(\mathrm{CH}_{2}\right)_{4} \mathrm{CONH}\left(\mathrm{CH}_{2}\right)_{5} \mathrm{COOC}_{2} \mathrm{H}_{5}$

$\mathrm{H}_{5} \mathrm{C}_{2} \mathrm{OOC}\left(\mathrm{CH}_{2}\right)_{5} \mathrm{OOC}\left(\mathrm{CH}_{2}\right)_{4} \mathrm{COO}\left(\mathrm{CH}_{2}\right)_{5} \mathrm{COOC}_{2} \mathrm{H}_{5}$

$\mathrm{H}_{5} \mathrm{C}_{2} \mathrm{OOCHN}\left(\mathrm{CH}_{2}\right)_{6} \mathrm{HNOC}\left(\mathrm{CH}_{2}\right)_{4} \mathrm{CONH}\left(\mathrm{CH}_{2}\right)_{6} \mathrm{NHCOOC}_{2} \mathrm{H}_{5}$

$\mathrm{H}_{5} \mathrm{C}_{2} \mathrm{OOCHN}\left(\mathrm{CH}_{2}\right)_{6} \mathrm{OOC}\left(\mathrm{CH}_{2}\right)_{4} \mathrm{COO}\left(\mathrm{CH}_{2}\right)_{6} \mathrm{NHCOOC}_{2} \mathrm{H}_{5}$

$\mathrm{ClOC}\left(\mathrm{CH}_{2}\right)_{4} \mathrm{COCl}+\mathrm{NH}_{2}\left(\mathrm{CH}_{2}\right)_{5} \mathrm{COOH} \underset{\mathrm{NaOH}}{\stackrel{\text { 水 }}{\longrightarrow}}$

$\mathrm{HOOC}\left(\mathrm{CH}_{2}\right)_{5} \mathrm{HNOC}\left(\mathrm{CH}_{2}\right)_{4} \mathrm{CONH}\left(\mathrm{CH}_{2}\right)_{5} \mathrm{COOH}$

$\mathrm{OCN}\left(\mathrm{CH}_{2}\right)_{4} \mathrm{NCO}+\left\{\begin{array}{l}\mathrm{NH}_{2}\left(\mathrm{CH}_{2}\right)_{6} \mathrm{NHCOOC}_{2} \mathrm{H}_{5} \\ \mathrm{HO}\left(\mathrm{CH}_{2}\right)_{6} \mathrm{NHCOOC}_{2} \mathrm{H}_{5} \\ \mathrm{NH}_{2}\left(\mathrm{CH}_{2}\right)_{5} \mathrm{COOC}_{2} \mathrm{H}_{5}\end{array}\right\}$ ベンゼン中

$\mathrm{H}_{5} \mathrm{C}_{2} \mathrm{OOCHN}\left(\mathrm{CH}_{2}\right)_{6} \mathrm{HNOCHN}\left(\mathrm{CH}_{2}\right)_{4} \mathrm{NHCOHN}\left(\mathrm{CH}_{2}\right)_{6} \mathrm{NHCOOC}_{2} \mathrm{H}_{5}$ (B-1)

$\mathrm{H}_{5} \mathrm{C}_{2} \mathrm{OOCHN}\left(\mathrm{CH}_{2}\right)_{6} \mathrm{OOCHN}\left(\mathrm{CH}_{2}\right)_{4} \mathrm{NHCOO}\left(\mathrm{CH}_{2}\right)_{6} \mathrm{NHCOOC}_{2} \mathrm{H}_{5}$

$\mathrm{H}_{5} \mathrm{C}_{2} \mathrm{OOC}\left(\mathrm{CH}_{2}\right)_{5} \mathrm{HNOCHN}\left(\mathrm{CH}_{2}\right)_{4} \mathrm{NHCONH}\left(\mathrm{CH}_{2}\right)_{5} \mathrm{COOC}_{2} \mathrm{H}_{5}$
(B-2)

$(\mathrm{A}-1)$

$(\mathrm{A}-2)$

$(\mathrm{A}-3)$

(B-3)
またをーアミノカプロン酸から N-カルベトキシーを-ア ミノカプロン酸クロリドをつくりここれを原料として次 式のごとく中央に酸アミド結合 2 個を有するジウレタン (C-1)を合成した。

$\mathrm{H}_{5} \mathrm{C}_{2} \mathrm{OOCNH}\left(\mathrm{CH}_{2}\right)_{5} \mathrm{COCl}+\mathrm{NH}_{2}\left(\mathrm{CH}_{2}\right)_{6} \mathrm{NH}_{2}$

$$
\begin{array}{r}
\stackrel{\mathrm{NaOH}}{\stackrel{\text { 中 }}{\longrightarrow}} \\
\end{array}
$$

つぎにこれら長鎖ジェステル，またはジゥレタンを炭 素数 4 または 6 のジアミン, ジオールと重縮合させ, 前 記 [I]〜 [VI] の種々の組合わせをもった高分子をつくり, その电釆性を定性的に検した。

その結果电采性からみた良否は一応次の順で示される ことを知った。

ポリアミド〉ポリアミド・尿素 [II]〉ポリ尿素・ウレ タン [IV]〉ポリ尿素〉ポリアミド・ウレタン [III]〉ポリ ウレタン〉ポリ尿素・エステル[IV], ポリアミド・エス
$1.3 \varepsilon-$ ア 酸エチル， N-カルヘトキシヘキサメチレンジアミン N-カルベトキシアミノヘキサノール いずれも第 報”と同样にして合成した。

\section{$1.4 \mathrm{~N}$-カルベトキシーヒ-アミノカプロン酸クロリド}

まずN-カルベトキシーをーアミノカプロン酸を第 1 報 のとおり合成,ついで塩化チオニルで酸塩化物に変えた

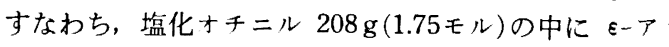
ノカプロン酸ウレタン化物 $142 \mathrm{~g}(0.70$ モル) を常温で 々に加えた後, $50^{\circ} \mathrm{C}$ に 2 時間保つ。まず過剩の塩化チ； ニルを初めは常圧で終りには減圧でできるだけ留去? る。次に残液に脱水ベンゼンを少量加え活性炭を入れ才 熱, 口過後, 減圧でベンゼンを留去すると黒褐色の液之 得られる。この操作を 2 回繰り返すと塩化チオニル臭 ほとんど消失し液の色もいくぶん淡色になる。収量 14

* 配列が不規則になる可能性は十分にあるが，それでも分子: 体に含まれる結合の比率は変らない。 
第 1 表重縮合の結果

\begin{tabular}{|c|c|c|c|c|c|c|c|}
\hline $\begin{array}{l}\text { 化合物 } \\
\text { 略 号 }\end{array}$ & \multicolumn{2}{|c|}{$\mathrm{NH}_{2}\left(\mathrm{CH}_{2}\right)_{n} \mathrm{NH}_{2}$} & \multicolumn{3}{|c|}{$\mathrm{HO}\left(\mathrm{CH}_{2}\right)_{n} \mathrm{OH}$} & \multicolumn{2}{|l|}{$\mathrm{NH}_{2}\left(\mathrm{CH}_{2}\right)_{8} \mathrm{OH}$} \\
\hline$A^{\prime}-1$ & ポリアミド@ & $\begin{array}{l}n=4, \mathrm{mp} \text { 約 } 186^{\circ} \mathrm{C} \\
n=6, \mathrm{mp} \text { 約 } 150^{\circ} \mathrm{C}\end{array}$ & [I] & $\triangle$ & $n=6$ & $\begin{array}{c}\text { ポリアミド・エステル } \\
(3: 1)\end{array}$ & $\triangle$ \\
\hline A-2 & [I] & $n=6$ & ポリエステル & $\triangle$ & $n=6$ & $\begin{array}{c}\text { ポリアミド.エステル } \\
(1: 3)\end{array}$ & $x$ \\
\hline A-3 & [II] & $\begin{array}{l}n=4, \mathrm{mp} \text { 約 } 165^{\circ} \mathrm{C} \\
\boldsymbol{n}=6, \mathrm{mp} \text { 約 } 155^{\circ} \mathrm{C}\end{array}$ & [III] & 0 & $n=6$ & $\begin{array}{c}\text { ポリアミド・尿素・ウレタン } \\
(2: 1: 1)\end{array}$ & 0 \\
\hline$A-4$ & [IV] & $n=6$ & {$[\mathrm{~V}]$} & $\triangle$ & $n=6$ & $\begin{array}{c}\text { ポリエステル・层素・ウレタン } \\
(2: 1: 1)\end{array}$ & $\triangle$ \\
\hline B-1 & ポリ尿素 & $n=6$ & [VI] & $O \sim$ & $\begin{array}{l}n=4 \\
n=6\end{array}$ & $\begin{array}{c}\text { ポリ杘素・ウレタン } \\
(3: 1)\end{array}$ & O \\
\hline B-2 & [VI] O & $n=6$ & ポリウレタンけ† & $\bigcirc$ & $n=6$ & $\begin{array}{c}\text { ポリ尿素・ウレタン } \\
(1: 3)\end{array}$ & $\triangle$ \\
\hline B-3 & {$[\mathrm{II}]^{++\dagger}$} & $n=6$ & [IV] & $\triangle$ & $n=6$ & $\begin{array}{c}\text { ポリアミド・尗素・エステル } \\
(1: 2: 1)\end{array}$ & $\triangle$ \\
\hline C-1 & [II] & $n=6 \mathrm{mp}$ 約 $145^{\circ} \mathrm{C}$ & [III] & 0 & $n=6$ & $\begin{array}{c}\text { ポリアミド・㲾素・ウレタン } \\
(2: 1: 1)\end{array}$ & 0 \\
\hline
\end{tabular}

約 $150^{\circ} \mathrm{C}$ 以上の触点を有し，淡色不透明で曳釆性，延伸性を有するもの。

○（）に準ずるもので，融点が低く，电系性流あるが，延伸性にそしいもの。

$\triangle$ かなりの的点を有するが，口ウ状のもの。

× 反応途中結晶が析出するか，またはアメ状で十分高分子にならないもの。

(注) † $n=6$ の堨合は 6-ナイロンと 6-6・+イロンの共縮合体に相当する。

†十 パーロンUに同じ，ただしウレタンの結合方向が異なる。

†十ここの高分子はすでに岩倉”によっても報告されているが，他上比較するため追試した。なお氏は原料としてジカルボン酸を 用いているが，われわれはジェステルを用いた。

$\mathrm{g}(91 \%)$ 。なおこのものは减圧蒸留すると分解するので そのまま用いた。

$1.5 \mathrm{~N}, \mathrm{~N}^{\prime}-$ ビス-(5-カルベトキシペンチル)アジパ

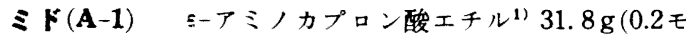
ル)をベンゼン $200 \mathrm{cc}$ に溶し，氷泠かきまぜながら，ア ジピン酸ジクロリド $21.9 \mathrm{~g}(0.12$ モ $)$ を徐々に滴下する。 生成塩化水素を中和するために併行して炭酸かリ $41.4 \mathrm{~g}$ (0.3モル)を少量あて加える。この間温度は $10^{\circ} \mathrm{C}$ に保 つ。滴下終了後䄪 $40^{\circ} \mathrm{C}$ に $1 \sim 2$ 時間保つ。その後, 内 容物を水 $100 \mathrm{cc}$ 中に注き無機塩を溶解し去り, ベンゼ ン層を希酸，アルカリ水，水で洗い，ボウ硝で乾燥後べ ンゼンを留去して目的物を得た。收量 $32.1 \mathrm{~g}(75 \%)$ 。 ンゼンより再結晶, $\mathrm{mp} 103^{\circ} \mathrm{C}$ 。

1.6 アシビン酸ビス-(5-カルベトキシペンチル)エ ステル(A-2) ยーオキシカプロン酸エチル1 $19.2 \mathrm{~g}$ (0.12モル)をペンゼン $100 \mathrm{cc}$ に溶し,アジピン酸ジクロ リド $11.3 \mathrm{~g}(0.06$ モル $)$ を用い, $(\mathrm{A}-1)$ の場合同様に反応を 行ない目的物を得た。収量 $17 \mathrm{~g}(66 \%)$ 。bp $228 \sim 230^{\circ} \mathrm{C} /$ $4 \mathrm{~mm}$ 。

$1.7 \mathrm{~N}, \mathrm{~N}^{\prime}-$ ビス-(6-カルベトキシアミノへキシル) ア ジパミト(A-3)Ｎ-カルベトキシへキサメチレンジア ミン1) $18.8 \mathrm{~g}(0.1$ モ)をヘンゼン $350 \mathrm{cc}$ に溶し,アジピ ン酸ジクロリド $9.5 \mathrm{~g}(0.052$ モ $)$ を用い，前同梯に反応
を行なう。収量 $20 \mathrm{~g}(82 \%$ \%)。アルコールより再結晶, mp $160 \sim 161^{\circ} \mathrm{C}_{\text {。 }}$

1.8 アジピン酸ビス-(6-カルベトキシアミノへキシ ル)エステル $(\mathbf{A}-4) \quad \mathrm{N}$-カルベトキシアミノへキサ， ール1) $18.9 \mathrm{~g}(0.1$ モル $)$ をベン゙ン $100 \mathrm{cc}$ に溶し、アジピ ン酸ジクロリド $9.5 \mathrm{~g}(0.052$ ル $)$ を用い, 前同様に反応 を行なう。収量 $19 \mathrm{~g}(78 \%)$ 。リグロイン・ベンゼンより 再結晶, $\mathrm{mp} 32 \sim 33^{\circ} \mathrm{C}$ 。

$1.9 \mathrm{~N}, \mathrm{~N}^{\prime}-$ ビス(5-カルボキシペンチル)アジパミド

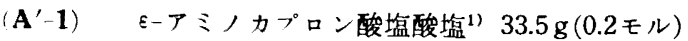
を水 $50 \mathrm{cc}$ に溶し, アルカリで弱アルカリ性にした後, アジピン酸ジクロリド $21.9 \mathrm{~g}(0.12$ モル $)$ と $10 \%$ アルカ リ水と併行して滴下する。この間温度は $10 \sim 15^{\circ} \mathrm{C}$ に保 つ。後 $40 \sim 50^{\circ} \mathrm{C}$ で 1 時間かきまぜを続ける。反応後, 希塩酸で酸性にすると目的物が析出してくる。収量 $28 \mathrm{~g}$ $(75 \%)$ 。水より再結晶, $\mathrm{mp} 144 \sim 145^{\circ} \mathrm{C}$ 。

$1.101,1^{\prime}$-テトラメチレンビス-[3-(6-カルヘトキ シアミノヘキシル)尿淎] (B-1) N-カルベトキシへキ サメチレンジアミン1) $37.6 \mathrm{~g}(0.2$ モ)をベンゼン $350 \mathrm{cc}$ に溶しこれにテトラメチレンジィソシテナート $16.8 \mathrm{~g}$ $(0.12$ モル $)$ の $20 \mathrm{cc}$ ペンゼン溶液を $10^{\circ} \mathrm{C}$ で滴下する。 後定温で 1 時間かきまぜる。生成沈殿を口過し乾燥す

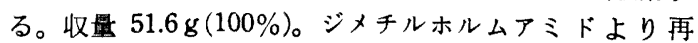


結晶, $\mathrm{mp} 198^{\circ} \mathrm{C}$ 。

$1.11 \mathrm{~N}, \mathrm{~N}^{\prime}$-ビス-[6-(カルヘトキシアミノ)カルボ ヘキシル]テトラメチレンジアミン(B-2) N-カルベト

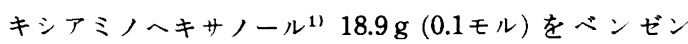
$200 \mathrm{cc}$ に溶し, これにテトラメヂレンジイソシァナート $7.3 \mathrm{~g}(0.05$ モル $)$ の $20 \mathrm{cc}$ ベンゼン溶液を反応させ, 後 ベンゼンを留去すると目的物が得られる。収量 $24.9 \mathrm{~g}$

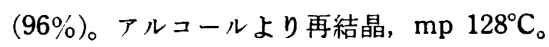

$1.121,1^{\prime}$-テトラメチレンービス-[3-(6-カルヘトキ シペンチル)尿塛](B-3) $31.8 \mathrm{~g}(0.2$ モ) をベンゼン $350 \mathrm{cc}$ に溶し、これにテト ラメチレンジイソジナート $16.8 \mathrm{~g}(0.12$ モル)の $20 \mathrm{cc}$ ベンゼン溶液を加えて得る。収量 $45 \mathrm{~g}(100 \%)$ ○アル ールより再結晶, $\mathrm{mp} 170 \sim 171^{\circ} \mathrm{C}$ 。

$1.13 \mathrm{~N}, \mathrm{~N}^{\prime}$-ビス-(5-カルベトキシアミノヘキサノ イル)へキサメチレンジアミン(C-1) へキサメチレン ジアミン $29 \mathrm{~g}(0.25$ ル $)$ を水 $100 \mathrm{cc}$ に溶し, $10 \%$ 力七 イソーダ水 $300 \mathrm{cc}$ と $\mathrm{N}$-カルベトキシーを-アミノカプロ

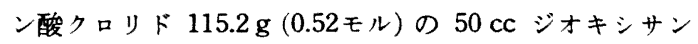
溶液を $15 \sim 20^{\circ} \mathrm{C}$ でかきませながら併行して滴下する。 滴下後 $40 \sim 50^{\circ} \mathrm{C}$ で 1 時間かきまぜる。塩酸で弱酸性に して吸收口過, 水洗, 乾燥すると褐色の目的物を得る。収 量 $81 \mathrm{~g}(71 \%)$ 。アルコール・水より再結晶, $\mathrm{mp} 149^{\circ} \mathrm{C}$ 。

1.14 ヘキサメチレンジアミン, 1, 4-フタンジオー ル市販品を使用した。

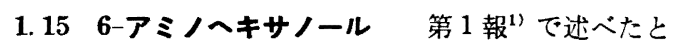
同様にして合成した。

1.16 テトラメチレンジアミン アジピン酸ジメチ ルから Curtius 反応 ${ }^{6)}$ で目的物の塩酸塩を得た。収率 $78 \%$ 。次にこれを遊離塩基に替え縮合に使用した。

$1.171,6$-ヘキサンジオール アジピン酸ジェチル を水素化アルミニウムリチウムで還元する方法7により
合成した。收率 $69 \%$ 。

また以上の化合物中新化合物の元素分析值を一括して 第 2 表に示した。

\section{2. 重縮 合}

$\left(\mathrm{A}^{\prime}-1\right),(\mathrm{A}-2),(\mathrm{A}-3) \cdots \cdots(\mathrm{C}-1)$ の各化合物と炭 素数 6 の脂肪族ジアミン, ジオール，アミノアルコール を無溶媒, 空素気流中で, $160 \sim 260^{\circ} \mathrm{C}, 3 \sim 7$ 時間加熱し, 縮合反応を行なった。一部のものについては炭素数 4 の ジアミン, ジオールとの縮合も検した。なお触媒として 粒状カセインーダを用いた場合もある。次に重縮合の例 を二,三示す。

2.1 ジウレタン $(\mathbf{A}-3)$ とテトラメチレンジアミンの重 縮合 ジウレタン $(\mathrm{A}-3) 4.86 \mathrm{~g}(0.01$ モル $)$ とテトラメ チレンジアミン $1.05 \mathrm{~g}(0.012$ モ) をよく混し、これに 触媒として少量のカセイカリを添加する。これを試験管 に入れ窒素ガス気流中に油浴中で加熱する。初め油浴 の温度が $160 \sim 180^{\circ} \mathrm{C}$ で 1 時間, さらに $240 \sim 260^{\circ} \mathrm{C}$ で 2〜3 時間加熱すると気泡の発生がほとんどやむ。放冷 後, 試験管を破砕して重合物を取り出し, ガラス板上で 溶融させて，とがったガラス棒で定性的に曳采性を調べ たところ，かなり良好で，また延伸性をも示した。生成 高分子は黄味を帯びた堅いもので, キ酸、水酢酸、フェノ ール，m-クレジールには可溶であるが，アルコール， ヘ ンゼンなどー般の有機溶剤には不溶である。融点は約 $165^{\circ} \mathrm{C}$ で, 極限粘度 $[\eta]=0.50\left(\mathrm{~m}-\right.$ クレゾール, $\left.25^{\circ} \mathrm{C}\right)$ を 示した。なおへキサメチレンジアミンとも同様重縮合を 行ない曳系性の良好なものを得た。この場合生成物の融 点は約 $155^{\circ} \mathrm{C}$, 極限粘度 $[\eta]=0.34\left(\mathrm{~m}-\right.$ クレゾール, $\left.25^{\circ} \mathrm{C}\right)$ であった。

2.2 ジウレタン $(\mathrm{C}-1)$ とへキサメチレンジアミンの

重縮合 ジウレタン(C-1) $4.86 \mathrm{~g}(0.01$ モル) と一キサ メチレンジアミン $1.39 \mathrm{~g}(0.012$ モ $)$ をよく混し, 前同様

第 2 表 元素分析值

\begin{tabular}{|c|c|c|c|c|c|c|c|}
\hline \multirow{2}{*}{$\begin{array}{c}\text { 化合物 } \\
\text { 略 号 }\end{array}$} & \multirow{2}{*}{ 分子式 } & \multicolumn{2}{|c|}{$\mathrm{C} \%$} & \multicolumn{2}{|c|}{$\mathrm{H}^{\circ}$} & \multicolumn{2}{|c|}{$\mathrm{N} \%$} \\
\hline & & 計 算 值 & 分析 值 & 計算值 & 分析 值 & 計 算 值 & 分析值 \\
\hline A-1 & $\mathrm{C}_{22} \mathrm{H}_{40} \mathrm{~N}_{2} \mathrm{O}_{6}$ & 61.65 & 61.59 & 9.41 & 9.57 & 6.54 & 6.70 \\
\hline$A^{\prime}-1$ & $\mathrm{C}_{18} \mathrm{H}_{32} \mathrm{~N}_{2} \mathrm{O}_{6}$ & 58.04 & 58.33 & 8.66 & 8.85 & 7.52 & 7.65 \\
\hline$A-2$ & $\mathrm{C}_{22} \mathrm{H}_{88} \mathrm{O}_{8}$ & 61.37 & 61.17 & 8.90 & 8.95 & - & - \\
\hline A-3 & $\mathrm{C}_{24} \mathrm{H}_{46} \mathrm{~N}_{4} \mathrm{O}_{6}$ & 59.23 & 59.53 & 9.53 & 9.52 & 11.51 & 11.77 \\
\hline$A-4$ & $\mathrm{C}_{24} \mathrm{H}_{44} \mathrm{~N}_{2} \mathrm{O}_{8}$ & 58.99 & 58.86 & 9.08 & 9.16 & 5.73 & 5.63 \\
\hline B-1 & $\mathrm{C}_{24} \mathrm{H}_{48} \mathrm{~N}_{8} \mathrm{O}_{8}$ & 55.79 & 55.80 & 9.36 & 9.17 & 16.27 & 16.50 \\
\hline B-2 & $\mathrm{C}_{24} \mathrm{H}_{46} \mathrm{~N}_{4} \mathrm{O}_{8}$ & 55.58 & 55.50 & 8.94 & 8.93 & 10.80 & 10.90 \\
\hline B-3 & $\mathrm{C}_{22} \mathrm{H}_{42} \mathrm{~N}_{4} \mathrm{O}_{6}$ & 57.61 & 57.59 & 9.23 & 9.42 & 12.22 & 11.99 \\
\hline $\mathrm{C}-1$ & $\mathrm{C}_{24} \mathrm{H}_{46} \mathrm{~N}_{4} \mathrm{O}_{6}$ & 59.23 & 59.01 & 9.53 & 9.29 & 11.52 & 11.38 \\
\hline
\end{tabular}


重縮合を行ない曳糸性の良好な堅い淡黄色の高分子を得 た。溶媒に対する溶解性は前と同じである。融点は約 $145^{\circ} \mathrm{C}$ で, 極限粘度 $[\eta]=0.44\left(\mathrm{~m}-\right.$ クレジール, $\left.25^{\circ} \mathrm{C}\right)$ で あった。

2.3 ジカルポン酸 $\left(\mathrm{A}^{\prime}-1\right)$ とテトラメチレンジアミン の重縮合* ジカルボン酸 $\left(\mathrm{A}^{\prime}-1\right) 3.72 \mathrm{~g}(0.01$ モル) と

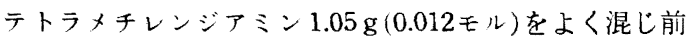
同様重縮合を行なった。生成高分子は白濁色で良好な电 釆性を示す。溶媒に対する溶解性も前同様で, ギ酸, 水 酢酸,フェノール， m-クレゾールにのみ可溶である。融 点は約 $186^{\circ} \mathrm{C}$ で, 極限粘度 $[r]=0.81(\mathrm{~m}$ ークレジール， $\left.25^{\circ} \mathrm{C}\right)$ であった。

*この場合生成物はポリアミドである。

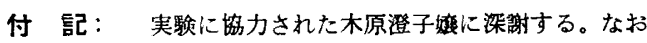
本報告は昭和 33 年 4 月, 日本化学会第 11 年会に㧧、て発表 したものである。

\section{文献}

1)小田, 時浦, 永坂, 岡野: 高化, 15, 137(1959)

2) 岩倉: 高化, 4, 308, 312, 323(1947)

3) R. Meyer: Ann., 347, 49(1906)

4) 岩倉, 宇野, 林: “高分子実験学講座”, 第 11 巻, 140, 共立出版 (1958)

5）岩會, 山田: “合成樹脂工業叢書”, 第 6 巻, 197, 誠 文堂新光社 (1947)

6) P.A.S. Smith : Org. Synth., 36, 69(1956)

7) R.F. Nystrom and W.G. Brown: J. Am. Chem. Soc., 69, $1197(1947)$

\title{
Syntheses of Condensation Polymers and Addition Polymers
}

\author{
III. Syntheses of Polymers Having Regularly Repeating Groups \\ by Polycondensation (Part 1 )
}

\author{
By Ryohei Oda*, Shohei Tokiura**, Akira Miyasu** \\ and Masaya Okano*
}

\begin{abstract}
Some aliphatic diesters and diurethanes were prepared by the reactions of adipoyl dichloride or tetramethylenediisocyanate with $\varepsilon$-aminocaproate, $\varepsilon$-oxycaproate, $\mathrm{N}$-carbethoxyhexamethylenediamine, or $\mathrm{N}$-carbethoxy-6-aminohexanol. They contain two amide, two ester, two urea, or two urethane groups in polymethylene linkage between two terminal ester or urethane groups. By the polycondensation reactions of these compounds with aliphatic diamines or diols of 4 or 6 carbon atoms, various polymers having the regular structure of -A-A-B-B- type were obtained. Among them the polyamide-ureas are fiber-forming, but the polyamide-esters, the polyurea-esters and the polyurethane-esters are not.
\end{abstract}

* Institute for Chemical Research, Kyoto University (Takatsuki, Osaka)

** Central Research Laboratory, Ube Industries, Ltd. (Ube, Yamaguchi) 